RESEARCH PAPER

\title{
Lawsuits and secondhand smoke
}

\author{
E L Sweda Jr
}

Tobacco Control 2004;13(Suppl I):i61-i66. doi: 10.1136/tc.2003.004457

\begin{abstract}
Objective: This paper describes secondhand smoke (SHS) litigation over the past quarter century where non-smoking litigants have prevailed and attempts to decipher trends in the law that may impact the course of future cases.

Methods: Since the early 1980s, the author has sought and examined legal cases in which SHS exposure is an important factor. Law library searches using the official reporter system (for example, Shimp v. New Jersey Bell Telephone Co., 368 A.2d 408) have more recently been combined with computerised online searches using LexisNexis and Westlaw. The author has learned of other cases through personal correspondence and from articles in newspapers. Over 420 cases involving exposure to SHS were identified. Each case was reviewed and summarised.

Results: Since 1976, the year of the first reported SHS lawsuit, this type of litigation has increased both in number and in scope with increasing success. While it is common for initial cases to lose in a new area where the law eventually evolves, litigants and their lawyers who later bring similar cases can learn from those previous, unsuccessful cases. It is now apparent that the judicial branch has begun to recognise the need to protect the public-especially some of the most vulnerable members of our society-from the serious threat to their health that is exposure to SHS.

Conclusions: Successful cases brought on behalf of individuals exposed to SHS produce an additional benefit for the public health by both paving the way for other non-smoking litigants to succeed in their cases and persuading business owners and others voluntarily to make their facilities $100 \%$ smoke-free.
\end{abstract}

Edward L Sweda, Sen Attorney, Tobacco Control Resource Center, Northeastern University School of Law, Boston, Massachusetts; ed@ tplp.org n the landmark case of Shimp v. New Jersey Bell Telephone Co. $(1976)^{1}$ a New Jersey Superior Court judge ruled that the “...evidence is clear and overwhelming... cigarette smoke contaminates and pollutes the air, creating a health hazard not merely to the smoker but to all those around her who must rely on the same air supply. The right of an individual to risk his or her own health does not include the right to jeopardize the health of those who must remain around him or her in order to perform properly the duties of their jobs."

The 1976 ruling in Shimp came a full decade before US Surgeon General C Everett Koop issued his 1986 report, The health consequences of involuntary smoking, in which he concluded that "[i]nvoluntary smoking is a cause of disease, including lung cancer, in healthy non-smokers", and "[s]imple separation of smokers and non-smokers within the same air space may reduce, but does not eliminate, exposure of nonsmokers to environmental tobacco smoke". ${ }^{2}$

For more than a quarter of a century since that historic ruling on behalf of an office worker from New Jersey, court cases affecting the rights of non-smokers seeking relief from the hazards of secondhand smoke (SHS) have arisen in a variety of different settings.

This article reviews some of the highlights of the SHS related litigation that has occurred across the USA during the past 27 years and will focus on cases where non-smoking plaintiffs have prevailed. During that span of time, both the number of SHS cases and the likelihood of success for litigants who are the victims of exposure to SHS have increased. Societal recognition of the health risks of SHS exposure has increased as well.

\section{METHODS}

Law library searches using the official reporter system (for example, Shimp v. New Jersey Bell Telephone Co., 368 A.2d 408) were combined with computerised online searches using LexisNexis and Westlaw to identify cases where SHS was a feature of the case. This analysis resulted in the identification of more than 420 cases. For the purpose of this paper, only cases where litigants were victorious in their suit are described. These cases are summarised in table 1. In order to examine trends in these nature these cases over time, each case was categorised by type, as follows: negligence; worker's compensation and disability benefits; discrimination based on disabilities; smoke seepage from one unit into another in a multi-unit building; child custody disputes; prisoner's rights; assault and/or battery; and cases where the defendants are the tobacco companies themselves.

\section{NEGLIGENCE}

In Husain, et al. v. Olympic Airways (2000), ${ }^{3}$ a case filed in federal court in California, plaintiffs brought a wrongful death action under the liability provisions of the Warsaw Convention, which normally limits recovery in cases involving "accidents" on airlines to a maximum of $\$ 75000$. After a non-jury trial in the spring of 2000, the court found the defendant liable in the amount of $\$ 700000$. The court found as follows: "On an international passenger flight in January 1998, Dr. Abid M. Hanson, a nonsmoker who suffered from asthma, inhaled a significant amount of second-hand smoke and died in the company of his wife and three children. Dr. Hanson was not seated in the 'smoking' section of the airplane on which he died, but was in a seat three rows ahead. Considerable ambient smoke was present at this location. Had Olympic Airways' flight crew responded appropriately to the repeated requests to move Dr. Hanson from this area, he might be alive today." The court ruled that the flight attendant's refusal, after three impassioned

Abbreviations: ADA, Americans With Disabilities Act; ETS, environmental tobacco smoke; FAMRI, Flight Attendant Medical Research Institute; PWDCRA, Persons with Disabilities Civil Rights Act; SHS, secondhand smoke 
Table 1 Secondhand smoke (SHS) cases, 1976 to 2003

\begin{tabular}{|c|c|c|c|c|}
\hline Name of case & Year & State & Type of case & Result \\
\hline $\begin{array}{l}\text { Shimp v. New Jersey Bell } \\
\text { Telephone Co }\end{array}$ & 1976 & NJ & Negligence & Non-smoking (NS) office worker gets relief from exposure to SHS \\
\hline Husain v. Olympic Airways & 2000 & CA & Negligence & $\begin{array}{l}\text { Family of NS passenger who died from exposure to SHS receives money } \\
\text { damages }\end{array}$ \\
\hline $\begin{array}{l}\text { Magaw v. Middletown Board } \\
\text { of Education }\end{array}$ & 1998 & NJ & Workers' compensation & Teacher with cancer caused by exposure to SHS receives compensation \\
\hline Ubhi v. State Comp Ins Fund & 1990 & CA & Workers' compensation & Waiter with heart attack caused by exposure to SHS receives compensation \\
\hline Staron v. McDonald's Corp & 1993 & $\mathrm{CT}$ & Disability discrimination & Asthmatic plaintiffs' case proceeds, McDonald's decides to go smoke-free \\
\hline $\begin{array}{l}\text { Homeyer v. Stanley Tulchin } \\
\text { Associates }\end{array}$ & 1995 & IL & Disability discrimination & NS worker's case proceeds \\
\hline Bond v. Sheahan & 2001 & IL & Disability discrimination & NS corrections officer's case proceeds \\
\hline $\begin{array}{l}\text { Zimmerman v. Dept. of } \\
\text { Corrections }\end{array}$ & 2002 & MI & Disability discrimination & NS corrections office's case proceeds \\
\hline $\begin{array}{l}\text { 50-58 Gainsborough St. v. } \\
\text { Haile }\end{array}$ & 1998 & MA & Smoke seepage & NS tenant recovers rent due effect of SHS on her quiet enjoyment of the apartment \\
\hline Daniel v. Daniel & 1998 & GA & Child custody & Smoking mother loses custody of asthmatic child to NS father \\
\hline Skidmore-Shafer v. Shafer & 1999 & $\mathrm{AL}$ & Child custody & Mother who smoked around child with health problems loses custody to NS father \\
\hline $\begin{array}{l}\text { In Re. Julie Anne, A Minor } \\
\text { Child }\end{array}$ & 2002 & $\mathrm{OH}$ & Child custody & Judge issues restraining order against both parents smoking around the child \\
\hline $\begin{array}{l}\text { In re. Guardianship of } \\
\text { A Minor Child }\end{array}$ & 2003 & MA & Child custody & A child's paternal grandparents lose custody because they smoke in his presence \\
\hline Helling v. McKinney & 1993 & NV & Prisoner & $\begin{array}{l}\text { US Supreme Court rules that SHS exposure in prison can be cruel and unusual } \\
\text { punishment, proscribed by the 8th Amendment of the US Constitution }\end{array}$ \\
\hline Alvarado v. Litscher & 2001 & WI & Prisoner & $\begin{array}{l}\text { Asthmatic inmate claims that prison officials violated his } 8 \text { th Amendment } \\
\text { protection against cruel and unusual punishment; his lawsuit proceeds }\end{array}$ \\
\hline Atkinson v. Taylor & 2003 & DE & Prisoner & NS prisoner's SHS and retaliation claims can proceed \\
\hline $\begin{array}{l}\text { Leichtman v. WLW Jacor } \\
\text { Communications, Inc }\end{array}$ & 1994 & $\mathrm{OH}$ & Assault and battery & $\begin{array}{l}\text { NS guest on radio show claims host deliberately blew smoke at him; lawsuit } \\
\text { proceeds }\end{array}$ \\
\hline $\begin{array}{l}\text { Broin et al. v. Philip Morris } \\
\text { Companies, Inc }\end{array}$ & 1991 & $\mathrm{FL}$ & $\begin{array}{l}\text { Tobacco company } \\
\text { defendants }\end{array}$ & $\begin{array}{l}\text { NS flight attendants' class action lawsuit settled in 1997; claims of individuals can } \\
\text { proceed }\end{array}$ \\
\hline
\end{tabular}

requests by Dr Hanson's wife, to move him to an area farther away from the smoke produced by the smoking passengers, constituted an "accident" for purposes of the Warsaw Convention, that the accident was a primary cause of his death and that the flight attendant's refusal to move him was "wilful misconduct". Thus, the \$75000 cap on damages under the Warsaw Convention did not apply.

After concluding "that the plaintiffs should receive an award of non-economic damages equal to this Court's earlier award for economic damages", the court determined that the total award is \$1 400000 .

On 12 December 2002, the US Court of Appeals for the Ninth Circuit, ${ }^{4}$ ruled that the district court's "findings and conclusions are well-grounded in the record. Olympic's argument asks this Court to substitute its judgment and second-guess the district court. This we cannot do... Therefore, we affirm the judgment of the district court." On 27 May 2003, the US Supreme Court agreed to consider Olympic Airways' appeal. Oral arguments took place on 12 November 2003.

\section{WORKER'S COMPENSATION AND DISABILITY BENEFITS}

During the past two decades, non-smokers who have been harmed by exposure to on-the-job SHS have been awarded worker's compensation benefits and disability benefits. In one such case, Magaw v. Middletown Board of Education, New Jersey Department of Labor, Division of Workers' Compensation, ${ }^{5}$ (1998), a physical education teacher's tonsillar cancer was caused by SHS, according to a worker's compensation judge. The judge awarded Magaw \$45000 in temporary disability benefits and also ordered the Middletown Board of Education to pay outstanding medical bills, provide future treatment, and restore sick time that he had used up. The judge ruled: "I am satisfied that [the petitioner] has proven even beyond the preponderance of credible evidence that [his] tonsillar cancer was caused by exposure to second-hand smoke during the twenty-six years that he shared an office with a co-employee who was a chain-smoker."

A state appeals panel ${ }^{6}$ upheld Magaw's monetary award but ruled that he would have to go back to the school board to seek reimbursement for the sick leave time he used up. The New Jersey Supreme Court ${ }^{7}$ refused to hear the school district's second appeal, thus letting the lower court ruling stand. Magaw was awarded about $\$ 53000$ for medical costs and \$20 000 for legal costs.

In Ubhi v. State Compensation Insurance Fund, Cat'n'Fiddle Restaurant (1990), ${ }^{8}$ a vegetarian, non-smoking waiter received a \$10 000 settlement for a heart attack he suffered after five years of working in a smoke filled restaurant. Also as part of the settlement, the California Workers' Compensation Appeals Board agreed to cover his medical bills, which amounted to about $\$ 85000$.

\section{DISCRIMINATION BASED ON DISABILITIES}

In Staron, et al. v. McDonald's Corporation (1993), ${ }^{9}$ plaintiffs brought an action in federal court in Connecticut under the American with Disabilities Act, arguing that the presence of tobacco smoke in the defendant's restaurants prevents the plaintiffs from having the opportunity to benefit from the defendant's goods and services. The plaintiffs, all of whom have adverse reactions when in the presence of smoke, also allege that the defendant's restaurants are places of public accommodation under 42 U.S.C. 12181. They sought an injunction against smoking in the defendant's restaurants, "thereby giving the plaintiffs equal access to said restaurants". However, a district court judge dismissed the case.

On 4 April 1995, the US Court of Appeals for the Second Circuit reversed ${ }^{10}$ the judgments of the district court, ruling that "we find that plaintiffs' complaints do on their face state a cognizable claim against the defendants under the Americans with Disabilities Act". The court noted: "the determination of whether a particular modification is 'reasonable' involves a fact-specific, case-by-case inquiry that considers, among other factors, the effectiveness of the 
modification in light of the disability in question and the cost to the organization that would implement it... We see no reason why, under the appropriate circumstances, a ban on smoking would not be a reasonable modification." The Staron lawsuit was filed in March 1993; within a year, McDonald's had announced its decision to ban smoking in all of its corporately owned restaurants. ${ }^{11}$

In Homeyer v. Stanley Tulchin Associates, Inc., et al., (1995), ${ }^{12}$ a woman suffering from chronic severe allergic rhinitis and sinusitis sought a smoke-free work environment and sued her former employer after it "repeatedly refused to provide" the plaintiff with a reasonable accommodation of her disability. Shortly after the plaintiff filed an Americans With Disabilities Act (ADA) discrimination claim with the Equal Employment Opportunity Commission and a worker's compensation claim, she was terminated. So, she filed suit, alleging violations of the ADA and an Illinois statute that prohibits retaliatory discharge. A federal judge granted the defendants' motion to dismiss the complaint, saying "that not every impairment that affects a person's major life activities is a substantially limiting one". "Homeyer does not, and cannot, allege that her sensitivity to [environmental tobacco smoke] substantially limits her ability to find employment as a typist generally. Thus, Homeyer is not a qualified individual with a disability, and, accordingly, is not entitled to the protections of the ADA."

However, the US Circuit Court of Appeals for the Seventh Circuit $^{13}$ unanimously reversed the dismissal. Noting that the district court had ignored Homeyer's claim that she was disabled in that her breathing, a major life activity, was affected by SHS, the court of appeals ruled that "we cannot say at this stage that it would be impossible for her to show that her chronic severe allergic rhinitis and sinusitis either alone or in combination with ETS substantially limits her ability to breathe".

In Bond v. Sheahan (2001), ${ }^{14}$ the plaintiff sued the defendant in his official capacity as Sheriff of Cook County for disability discrimination under the ADA. Working as a corrections officer and after suffering from a pulmonary embolism, Ms Bond began complaining about the presence of SHS at her workplace. While the Sheriff's Department codified a smoking policy in 1990, smoking nonetheless continued in all areas of the facility. In March 1995, Ms Bond was diagnosed with asthma. After her asthma worsened and exposure to SHS continued, Ms Bond resigned effective 28 February 1998. She sued, claiming that the defendant discriminated against her in violation of the ADA by constructively discharging her because of her asthma, a condition aggravated by the SHS. The court dismissed the defendant's motion for summary judgement, ruling that genuine issues of material fact exist concerning whether she was "disabled" for purposes of the ADA-specifically whether she is substantially limited in the major life activity of breathing.

In addition to the federal ADA, state laws barring discrimination against the disabled can be effective tools to protect non-smokers from exposure to SHS. In Zimmerman $v$. Department of Corrections (2002), ${ }^{15}$ after the plaintiff was hired as a corrections officer, he developed an increasing allergic reaction to SHS. Although the defendant had a policy that banned smoking in the housing units where plaintiff worked, he maintained that the policy was not enforced and that he suffered such a severe reaction to the smoke that he was disabled under the Persons with Disabilities Civil Rights Act (PWDCRA) because it interfered with the major life activity of breathing. He also contended that his disability was unrelated to his ability to function as a corrections officer because breathing SHS is not a prerequisite for his position. The defendant filed a motion for summary disposition; after a hearing, the trial court denied the motion, concluding that it was a question of fact whether the plaintiff was improperly discriminated against. The Court of Appeals of Michigan affirmed the denial of the defendant's motion, ruling that the "fact plaintiff could otherwise care for himself and perform various physical activities does not necessarily render him outside the protection of the PWDCRA".

\section{SMOKE SEEPAGE}

Since 1991, there have been at least 14 cases involving allegations of SHS seeping from one unit into another in a multi-unit dwelling. In 1998, a Massachusetts case broke new ground when a non-smoker refused to pay rent because of SHS exposure from a smoky bar on the first floor of her apartment. The tenant withheld the rent, alleging that the amounts of smoke seeping into her apartment deprived her of the quiet enjoyment of that apartment. A Housing Court judge ruled that the amount of smoke from the bar below had made the apartment "unfit for smokers and nonsmokers alike". The judge further ruled that "the evidence does demonstrate to the Court the tenants' right to quiet enjoyment was interfered with because of the second-hand smoke that was emanating from the nightclub below" 50-58 Gainsborough St. Realty Trust v. Haile, et al., (1998). ${ }^{16}$

As Kline has pointed out, there "are several legal theories available for residents of multiple dwelling residential buildings who are affected by ETS incursion", ${ }^{17}$ nuisance, covenant of quiet enjoyment and warranty of habitability. Additionally, the use of state regulations such as a sanitary code can "provide an effective, existing vehicle for resolution of ETS incursion problems". ${ }^{17}$ Similarly, a resident of a mobile home park, to gain access to the park's clubhouse successfully, used the Federal Fair Housing Act, which bans discrimination against the disabled and families with children. $^{18}$

\section{CHILD CUSTODY}

During the past 15 years, legal disputes over child custody where SHS has become an issue have occurred in at least 22 states across the USA. In Daniel v. Daniel, (1998), ${ }^{19}$ the mother was given legal and physical custody of the child when the parties divorced. After the divorce, the child developed asthma. At the time the child was living in an apartment with her mother who smoked and with her mother's boyfriend, who also smoked. The child made several trips to the doctor for asthma or other respiratory related matters. The trial court found that there was a sufficient change in circumstances to justify a change in custody to the father. The Court of Appeals of Georgia affirmed the judgment of the trial court, ruling that "the fact that the mother continued to smoke inside the apartment for almost three years after the child was diagnosed suggests that she was not adequately concerned about the child's health".

In Skidmore-Shafer v. Shafer (1999), ${ }^{20}$ the couple's separation agreement provided the mother with primary physical custody of their son. Later, the Calhoun (Alabama) Circuit Court awarded the father primary physical custody, holding that the change of custody would materially promote the child's best interests and that the good brought about by the change would offset any disruptive effect caused by uprooting the child. The court noted that during the child's entire life, "he has suffered respiratory infections and was diagnosed with asthma in February 1997, at which time he was also hospitalized with pneumonia". Despite these health problems and more than 20 visits to the doctor, the mother has continued to smoke around the child. The court noted that "it appears that the biggest and most blatant disregard for the health of the child is attributable to" the mother. The court further denounced the smoking around this child: "To 
do this to a child is no less child abuse than if you had deprived him of food or medical treatment." The Court of Civil Appeals of Alabama affirmed the court's judgment. "After carefully reviewing the entire record, we cannot say that the court erred in awarding primary physical custody of the child to the father."

In an Ohio case that garnered considerable attention from the news media in 2002, the Court, in In Re. Julie Anne, A Minor Child (2002), ${ }^{21}$ issued a restraining order against smokers to protect a child under the court's jurisdiction from the dangers of exposure to SHS and took judicial notice of the harmful nature of SHS on the health of children, citing numerous studies that characterised SHS as a carcinogen and a hazard to those exposed to it. The court concluded: "The overwhelming authoritative scientific evidence leads to the inescapable conclusion that a family court that fails to issue court orders restraining people from smoking in the presence of children under its jurisdiction is failing the children whom the law has entrusted to its care." The court granted a restraining order with provisions that "the mother and father are hereby restrained under penalty of contempt from allowing any person, including themselves, to smoke tobacco in the presence of the minor child Julie Anne. If smoking is allowed in the house in which the child lives or visits on a regular basis, it shall be confined to a room well ventilated to the outside that is most distant from where the child spends most of her time when there."

In a 2003 case in Massachusetts, ${ }^{22}$ the paternal grandparents of a 7 year old child were appointed as the child's guardians. The child's maternal grandmother later asked the court to remove the paternal grandparents as guardians and appoint her instead on the grounds that the child "is constantly exposed to dangers of secondhand smoke" while in the guardians' home.

The court took "judicial notice of current research that shows second-hand smoke or environmental tobacco smoke (ETS) can cause respiratory problems, including asthma and reactive airway disease, in children" and made a finding that exposing this child "to a smoking environment is contrary to his best interest". The court further found that the paternal grandparents "are largely unconcerned about the possibility" that the child "may continue to have asthma, reactive airway disease, allergies, or other respiratory problems". The court concluded that the fact that the paternal grandparents "have disregarded the multiple recommendations and warnings of physicians and continue smoking" in the child's presence "constitutes a sufficient change in the circumstances of their suitability as guardians". Therefore, the court terminated their role as guardians of the child and issued a decree regarding visitation that they "shall not smoke" in front of the child "or permit anyone else to do so".

\section{PRISONERS}

In McKinney v. Anderson (1991), ${ }^{23}$ an inmate who was housed in a cell with a heavy smoker brought a civil rights action against prison officials alleging violation of his Eighth Amendment right not to be subjected to "cruel and unusual punishment" due to his exposure to SHS. The US District Court for the District of Nevada granted a directed verdict for the prison officials; the inmate appealed. The US Court of Appeals for the Ninth Circuit reversed in part, ruling that even if the inmate cannot show that he suffers from serious, immediate medical symptoms caused by exposure to secondary smoke, compelled exposure to that smoke is nonetheless cruel and unusual punishment if at such levels and under such circumstances as to pose an unreasonable risk of harm to the inmate's health. The court noted: “... our society's attitudes have evolved to the point that unwanted exposure to ETS [environmental tobacco smoke] may amount to a violation of 'society's evolving standards of decency'." The court also ruled that Nevada's anti-smoking statute applies to prison libraries and creates a liberty interest in smoke-free prison libraries protected by the due process clause.

On 18 June 1993, the Supreme Court, by a seven to two vote in Helling v. McKinney (1993), ${ }^{24}$ held that "[w]e cannot rule at this juncture that it will be impossible for McKinney, on remand, to prove an Eighth Amendment violation based on exposure to ETS". The court also rejected "petitioners' central thesis that only deliberate indifference to current serious health problems of inmates is actionable under the Eighth Amendment". The Supreme Court affirmed "the holding of the Court of Appeals that McKinney states a cause of action under the Eighth Amendment by alleging that petitioners have, with deliberate indifference, exposed him to levels of ETS that pose an unreasonable risk of serious damage to his future health".

In the decade since the US Supreme Court's ruling in this area, courts have applied that standard to the facts that underlie other prisoners' claims of violations of their Eighth Amendment rights. In Alvarado v. Litscher, et al. (2001), ${ }^{25}$ a non-smoking inmate in Wisconsin who "suffers from severe chronic asthma," filed a civil rights lawsuit alleging that the state corrections department, the warden, and the health services manager violated his Eighth Amendment rights by acting with deliberate indifference to his complaints about his exposure to SHS. Alvarado "claims that other prisoners in the unit smoked in violation of prison policy because the guards were frequently not at their post to enforce the smoking ban". He also claimed that because smoking is permitted in common areas of the prison, he is unable to participate in programmes that would enhance his chances of being paroled. The district court denied the defendants' motion to dismiss. The Court of Appeals for the Seventh Circuit affirmed, ruling: "Alvarado's complaint stated an Eighth Amendment claim when he alleged that because of the prison officials' deliberate indifference, he was being exposed to levels of ETS which aggravated his chronic asthma, thereby endangering his existing health... He also stated a valid claim as to his future health under Helling $v$. McKinney."

In Atkinson v. Taylor, et al. (2003), ${ }^{26}$ Atkinson brought a civil rights lawsuit, alleging that the defendant prison officials subjected him to cruel and unusual punishment due to exposure to SHS. The prison officials' motion for summary judgment was denied by the US District Court for the District of Delaware. The prison officials appealed the denial of their motion. The US Court of Appeals for the Third Circuit affirmed the denial of the defendants' motion for summary judgment with respect to the inmate's SHS, retaliation and excessive force claims, thus allowing Atkinson's claims to go forward.

\section{ASSAULT AND/OR BATTERY}

A smoker's deliberate infliction of SHS onto another person can be the basis of a lawsuit alleging that battery-the unconsented to touching of another-has occurred.

In a case from Ohio, Leichtman $v$. WLW Jacor Communications, Inc., et al. (1994), ${ }^{27}$ a non-smoker who was a guest on a live radio show had cigar smoke blown in his face. He alleged that the act was done deliberately to cause him "physical discomfort, humiliation or distress", violated his right to privacy, constituted battery, and violated a Cincinnati Board of Health regulation. The trial court dismissed all of the plaintiff's claims. However, the Court of Appeals, First Appellate District of Ohio, reinstated the battery claim and affirmed the dismissal of the invasion of privacy and the health regulation claims. The court ruled that, as alleged in the complaint, "when Furman [one of the 
defendants] intentionally blew cigar smoke in Leichtman's face, under Ohio common law, he committed a battery". The case was later settled for an undisclosed sum.

\section{SUING TOBACCO COMPANIES}

In Broin, et al. v. Philip Morris Companies Inc., et al., ${ }^{28}$ seven current and former flight attendants who do not smoke sued the six major cigarette manufacturers for their having contracted lung cancer and other ailments or for facing increased risk of disease by inhaling tobacco smoke on airplanes. The plaintiffs, seeking class action status on behalf of 60000 non-smoking flight attendants, filed the suit on 31 October 1991. Seven months later, a Dade County Circuit Court Judge dismissed the class action aspect of the plaintiffs' complaint. However, a three judge panel of the District Court of Appeal of Florida, Third District unanimously reversed the order of dismissal and ordered that the class action allegations be reinstated.

On 12 December 1994, the Circuit Court for Dade County ruled $^{29}$ that the case could proceed as a class action. It was estimated that as many as 60000 current and former flight attendants could be a party to the suit. The class was defined as: "[a]ll non-smoking flight attendants, who are or who have been employed by airlines based in the United States and are suffering from diseases and disorders caused by their exposure to secondhand cigarette smoke in airline cabins." ${ }^{\prime 30}$ On 3 January 1996, the District Court of Appeals for the third district upheld the circuit court's ruling. ${ }^{31}$ In December 1996, the court (Kaye, J) authorised the mass notification of some 150000 to 200000 flight attendants so they can either sign up as plaintiffs or exclude themselves from the case to possibly pursue their own suits. The trial began on 2 June 1997 and proceeded for several months.

Lead plaintiff Norma Broin, who was at the time of the trial a 42 year old American Airlines flight attendant suffering from lung cancer, testified on 11 August 1997. A flight attendant for the previous 21 years, Ms Broin told the jury that she had regularly worked in "very, very, very, very dense cigarette smoke" when smoking on airlines was allowed and that the difference in air quality before airline smoking was effectively banned in 1990 compared to when she testified in 1997 was "absolutely night and day, significant difference" ${ }^{\prime 2}$

The plaintiff's presentation of evidence included testimony from Dr Michael Siegel of the Boston University School of Public Health and former US Surgeon General Julius Richmond. University of Utah cardiologist John H Holbrook testified that people exposed to SHS had an elevated risk of developing heart disease, including heart attacks and clogged arteries. "The evidence had been accumulating, and I will now say unequivocally it is a cause" of coronary heart disease, Dr Holbrook told the jury on 30 July 1997. A former tobacco researcher, Dr Freddy Homburger, testified that he found cancer of the larynx in laboratory hamsters exposed to cigarette smoke in $1973 .^{33}$

The tobacco industry began presentation of witnesses on 22 September 1997. Among the industry's witnesses was Michael Ogden, a chemist employed by RJ Reynolds Tobacco Co. On direct examination, Dr Ogden downplayed the significance of non-smokers' exposure to SHS. On cross examination, he was asked whether he believed that active smoking causes lung cancer in human beings. His response was that smoking is a "risk factor" for cancer but that he did not agree that smoking causes that disease. ${ }^{34}$

On 10 October 1997, the parties announced a proposed settlement whereby the defendants would pay $\$ 300000000$ to establish a research foundation-which was to become the Flight Attendant Medical Research Institute (FAMRI)—and agree that flight attendants harmed by SHS exposure aboard

\section{What this paper adds}

Hundreds of cases involving exposure to SHS have been reported over the past quarter century. This paper presents an analysis of some of the most significant victories for victims of SHS exposure. The increasing positive results of these cases have helped persuade government officials and private business owners to adopt smoke-free rules as the norm.

airlines can sue the tobacco companies regardless of statute of limitations issues. Individual actions can proceed with the burden of proof on the defendants on the issue of whether ETS exposure causes one of five diseases (emphysema, lung cancer, chronic obstructive pulmonary disease, chronic bronchitis, and chronic sinusitis) in non-smokers. By the 7 September 2000 deadline for filing such cases, more than 3000 flight attendants had done so. ${ }^{35}$ Videotaped testimony from the plaintiffs' experts in the Broin case is admissible evidence in these individual actions.

In an order dated 3 February 1998, Dade County Circuit Judge Robert Kaye approved the proposed settlement, calling it "fair reasonable, adequate and in the best interests of the class". Challengers for three individuals objected to the settlement. On 24 March 1999, the Third Circuit Court of Appeal unanimously denied the objectors' appeal of the settlement. The objectors decided not to appeal to the Florida Supreme Court.

Indeed, as the editorial by Daynard notes, ${ }^{36}$ a supposedly hopeless case resulted in an extraordinary settlement that both produced $\$ 300000000$ for research and facilitated the prosecution of claims by individual flight attendants whose health had been harmed by their on-the-job exposure to SHS. Additionally, this one case drew enormous public attention to the hazards of exposure to SHS and put human faces on the statistics that underlie the science of SHS.

In those individual cases, plaintiffs who are seeking damages on account of lung cancer, chronic bronchitis, emphysema, chronic obstructive pulmonary disease, or chronic sinusitis will have the burden of proof as to whether SHS can cause one of those diseases borne by the defendant cigarette companies who entered into the October 1997 settlement. As of December 2003, seven of these individual cases on behalf of flight attendants harmed by on-the-job exposure to SHS have gone to trial, with one of them resulting in a verdict for the plaintiff (French v. Philip Morris Inc. et al., a $\$ 5.5$ million verdict for the plaintiff on 18 June 2002; verdict reduced to $\$ 500000$ by the trial judge on 13 September 2002).*

\section{CONCLUSION}

It is apparent that the judicial branch has increasingly recognised the need to protect the public, especially some of the most vulnerable members of our society, from the serious threat to their health that is exposure to SHS. That practice will likely continue throughout the 21 st century as American society clamours for comprehensive laws and policies ${ }^{37}$ that, taken together, will help produce a smoke-free society.

*Among the other trials, four resulted in a defence verdict (Fontana $v$. Philip Morris Inc., verdict on 5 April 2001; Tucker v. Philip Morris Inc., verdict on 4 October 2002; Seal v. Philip Morris USA Inc., et al., verdict on 7 February 2003; and Routh v. Philip Morris USA, verdict on 14 October 2003), one in a mistrial (Quiepo v. Philip Morris Inc., et al., mistrial declared on 23 May 2002), and one in a defence verdict that was overturned by the trial judge (Janoff v. Philip Morris Inc., et al., defence verdict on 5 September 2002; trial judge overturned the defence verdict on 8 January 2003). That case will be retried. 
Individuals who have been harmed by exposure to SHS will continue to wage these courtroom battles as society becomes more cognisant of the damage that SHS inflicts on people. The number of examples of forceful quotes from judges who understand the dangers of SHS will make it easier for non-smokers to prevail in the litigation. This continuing trend will also help persuade those individuals and corporations in control of buildings and other facilities to go $100 \%$ smoke-free voluntarily, thereby avoiding risky litigation and improving the health of the public.

Since 1976, the year of the first reported SHS lawsuit, this type of litigation has increased both in number and in scope. With increasing levels of success for non-smoking litigants over the past decade, non-smokers exposed to the dangers of exposure to SHS will continue to seek relief from the courts for the foreseeable future.

\section{REFERENCES}

1 Shimp v. New Jersey Bell Telephone Co., 368 A. 2d 408 (New Jersey Superior Court 1976).

2 US Department of Health and Human Services. The health consequences of involuntary smoking. A report of the Surgeon General, 1986. Rockville, Maryland: Public Health Service, Centers for Disease Control, 1986. (DHHS Publication No (CDC) 87-8398.)

3 Husain, et al. v. Olympic Airways, 116 F. Supp.2d 1121 (United States District Court, Northern District of California 2000)

4 Husain, et al. v. Olympic Airways, 316 F.3d 829 (United States Court of Appeals, 9th Circuit 2002)

5 Magaw v. Middletown Board of Education, New Jersey Department of Labor, Division of Workers' Compensation, Claim Petition No. 95-005466, New Jersey, 1998.

6 Magaw v. Middletown Board of Education 731 A.2d 1196 (Superior Court of New Jersey, Appellate Division 1999).

7 Magaw v. Middletown Board of Education, New Jersey Department of Labor, Division of Workers' Compensation, 744 A.2d 1208 (New Jersey Supreme Court, 1999).

8 Ubhi v. State Compensation Insurance Fund, Cat'n'Fiddle Restaurant, No. SFO-0341691 (California Workers' Compensation Appeals Board 1990).

9 Staron, et al. v. McDonald's Corp., 872 F. Supp. 1092 (United States District Court, District of Connecticut 1993).

10 Staron, et al. v. McDonald's Corp., et al., 51 F.3d 353 (United States Court of Appeals, 2nd Circuit 1995).

11 PR Newswire. U.S. Court of Appeals allows nonsmokers to use Americans With Disabilities Act to clear the air in restaurants. Tobacco Products Liability Project, April 7, 1995.
12 Homeyer v. Stanley Tulchin Associates, Inc, et al, 1995 U.S. Dist. LEXIS 17114 (United States District Court, Northern District of Illinois 1995).

13 Homeyer v. Stanley Tulchin Associates, Inc., et al., 91 F.3d 959 (United States Court of Appeals, 7th Circuit 1996).

14 Bond v. Sheahan, 152 F. Supp.2d 1055 (United States District Court Northern District of Illinois 2001).

15 Zimmerman v. Department of Corrections, 2002 Mich. App. LEXIS 1419 (Court of Appeals of Michigan 2002).

16 50-58 Gainsborough St. Realty Trust v. Haile, et al., 13.4 Tobacco Products Litigation Reporter 2.302, No. 98-02279 (Boston (MA) Housing Court 1998).

17 Kline RL. Smoke knows no boundaries: legal strategies for environmental tobacco smoke incursions into the home within multi-unit residential dwellings. Tobacco Control 2000;9:201-5.

18 Inman B. Amended Fair Housing Act takes on new discrimination. San Francisco Examiner, January 15, 1995, E-1.

19 Daniel v. Daniel, 509 S.E.2d 117 (Court of Appeals of Georgia 1998).

20 Skidmore-Shafer v. Shafer, 770 So.2d 1097 (Court of Civil Appeals of Alabama 1999).

21 In Re. Julie Anne, A Minor Child, 121 Ohio Misc. 2d 20 (Ohio Court of Common Pleas 2002)

22 In re. Guardianship of a Minor Child, Probate and Family Court Dept., No. 01P1072 (Hampden (MA) Division, 2003).

23 McKinney v. Anderson, et al., 924 F.2d 1500, 6.2 TPLR 2.327 (United States Court of Appeals, 9th Circuit 1991).

24 Helling v. McKinney, 113 S.Ct. 2475, 509 U.S. 25, 125 L. Ed.2d 22, 61 LW 4648, 8.2 TPLR 2.201 (United States Supreme Court 1993).

25 Alvarado v. Litscher, et al., 267 F.3d 648 (United States Court of Appeals, $7^{\text {th }}$ Circuit 2001).

26 Atkinson v. Taylor, et al., 316 F.3d 257 (United States Court of Appeals, 3rd Circuit 2003).

27 Leichtman v. WLW Jacor Communications, Inc., et al., 634 N.E. 2d 697 (Court of Appeals, First Appellate District of Ohio 1994).

28 Broin, et al. v. Philip Morris Companies Inc., et al., 6.4 TPLR 3.465, No. 9149738 (1 $11^{\text {th }}$ Florida Circuit Court, Miami 1991).

29 Broin, et al. v. Philip Morris Companies Inc., et al., 9.6 TPLR 2.161 (Circuit Court for Dade County (Florida) 1994).

30 Sweda E. Landmark class-action suit puts secondhand smoke on trial; settlement announced. http://www.tobacco.neu.edu/tcu/12-97/ landmark_class.htm.

31 Philip Morris Inc., et al. v. Broin., et al., 672 So.2d 37, 1996 Fla. App. LEXIS 49 (District Court of Appeals of Florida, Third District 1996).

32 Sweda $\mathbf{E}$. Landmark class-action suit puts secondhand smoke on trial; settlement announced. http://www.tobacco.neu.edu/tcu/12-97/ landmark_class.htm.

33 Ibid.

34 lbid.

35 Sweda EL. Litigation on behalf of victims of environmental tobacco smoke, the experience from the USA. Eur J Public Health 2001;11:201-5.

36 Daynard RA. How did we get here? Tobacco Control 2004; 13:i3.

37 Halbfinger D. Antismoking measures gain in heart of tobacco country. New York Times, March 4, 2003, Al 